\title{
POTENSI EKSTRAK ETANOL BATANG KAPUK RANDU SEBAGAI ANTIBAKTERI
}

\author{
The Potency of Ethanolic Extract from Randu Kapok as Antibacterial Agent \\ $\underline{\text { Rina Hidayati Pratiwi }}$ \\ Jurusan Pendidikan Biologi, FTMIPA, Universitas Indraprasta PGRI, \\ Jalan Nangka No. 58 C (TB. Simatupang), Tanjung Barat, Jagakarsa, Jakarta, 12530 \\ rina.hp2012@gmail.com
}

\begin{abstract}
The aim of this research is to study inhibited ability of antibacterial compound were isolated from stem of Randu. That extracts were tested for their antibacterial activity to Escherichia coli, Staphylococcus aureus, and Bacillus cereus with disc and dilution methods. Phytochemistry were used for knowing bioactive compounds of that extracts. The extract of 30\% ethanol were able to suppress E. coli on $10 \mathrm{mg} / \mathrm{mL}$ concentration with 3.8 $\mathrm{mm}$ zone of inhibition, S. aureus with $3.6 \mathrm{~mm}$ zone of inhibition, and B. cereus with $4.3 \mathrm{~mm}$ zone of inhibition. Minimum Inhibitory Concentration (MIC) of $30 \%$ ethanol on $8 \mathrm{mg} / \mathrm{mL}$ concentration for E. coli, $6 \mathrm{mg} / \mathrm{mL}$ for S. aureus and B. cereus. The extract of $50 \%$ ethanol were able to suppress E. coli on $10 \mathrm{mg} / \mathrm{mL}$ concentration with $4.0 \mathrm{~mm}$ zone of inhibition, S. aureus with $4.2 \mathrm{~mm}$ zone of inhibition, and B. cereus with $3.9 \mathrm{~mm}$ zone of inhibition. Minimum Inhibitory Concentration (MIC) of 50\% ethanol on $8 \mathrm{mg} / \mathrm{mL}$ concentration for E. coli, $10 \mathrm{mg} / \mathrm{mL}$ for S. aureus and $8 \mathrm{mg} / \mathrm{mL}$ for B. cereus. The bioactive compounds were able to inhibit the growth of test bacteria are saponin, flavonoid and tannin.
\end{abstract}

Keywords: antibacteria, Bacillus cereus, Escherichia coli, Randu Kapok, Staphylococcus aureus

Abstrak-Penelitian ini bertujuan mengetahui daya hambat senyawa antibakteri batang kapuk randu terhadap bakteri Escherichia coli, Staphylococcus aureus, dan Bacillus cereus. Pengujian aktivitas antibakteri menggunakan metode difusi cakram, dilusi cair, nilai Konsentrasi Hambat Minimum (KHM) dan Konsentrasi Bunuh Minimum (KBM) terhadap ketiga jenis bakteri. Uji fitokimia dilakukan untuk mengetahui senyawa bioaktif ekstrak etanol batang kapuk randu yang dapat menghambat ketiga jenis bakteri patogen. Aktivitas antibakteri tertinggi pada ekstrak etanol 30\% dengan diameter zona hambat pada konsentrasi $10 \mathrm{mg} / \mathrm{mL}$ sebesar 3,8 mm terhadap E. coli; 3,6 mm terhadap S. aureus; dan 4,3 mm terhadap B. cereus. KHM ekstrak etanol $30 \%$ pada konsentrasi $8 \mathrm{mg} / \mathrm{mL}$ terhadap E. coli; $6 \mathrm{mg} /$ $\mathrm{mL}$ terhadap S. aureus; dan $6 \mathrm{mg} / \mathrm{mL}$ terhadap B. cereus; KBM pada konsentrasi $10 \mathrm{mg} / \mathrm{mL}$ terhadap S. aureus. Aktivitas antibakteri tertinggi pada ekstrak etanol $50 \%$ dengan diameter zona hambat pada konsentrasi $10 \mathrm{mg} / \mathrm{mL}$ sebesar $4 \mathrm{~mm}$ terhadap E. coli; 4,2 mm terhadap S. aureus; dan 3,9 mm terhadap B. cereus. KHM ekstrak etanol $50 \%$ pada konsentrasi $8 \mathrm{mg} / \mathrm{mL}$ terhadap E. coli; $10 \mathrm{mg} / \mathrm{mL}$ terhadap S. aureus; dan $8 \mathrm{mg} / \mathrm{mL}$ terhadap B. cereus; KBM pada $10 \mathrm{mg} / \mathrm{mL}$ terhadap B. cereus. Senyawa bioaktif yang berperan menghambat pertumbuhan ketiga jenis bakteri ialah saponin, flavonoid dan tanin.

Kata kunci: antibakteri, Bacillus cereus, Escherichia coli, kapuk randu, Staphylococcus aureus

\section{PENDAHULUAN}

Indonesia termasuk ke dalam native range yang merupakan wilayah persebaran asli dari kapuk randu. Kapuk randu telah banyak digunakan di beberapa negara, diantaranya di negara Afrika dan Amerika serta di negara Indonesia. Di beberapa negara seperti Afrika Barat, Afrika Tengah, dan Amerika Utara, ekstrak dari kapuk randu atau $C$. pentandra Gaertn. digunakan sebagai anti-inflamasi, analgesik, antibakteri, antidiabetes, antijamur, antimalaria, dan antioksidan (Asare and Oseni, 2012). Bagian tanaman kapuk randu yang digunakan untuk bidang pengobatan ialah bagian getah cair, kulit batang, dan bagian batangnya. Bagian getah cairnya banyak digunakan oleh masyarakat khususnya di wilayah Banten untuk 
mengatasi penyakit konjungtivitis (Pratiwi et al., 2012). Getah bening yang keluar dari batang kapuk randu tidak selalu mencukupi kebutuhan tersebut. Hal ini disebabkan oleh jumlah getah bening yang keluar dari batang sedikit dan waktu keluarnya singkat di pagi hari sebelum matahari terbit. Oleh karena itu diperlukan alternatif dalam pemanfaatan bagian lain dari kapuk randu yaitu dengan menggunakan batang kapuk randu. Batang kapuk randu diduga berpotensi memiliki kemampuan antibakteri dan memiliki kandungan senyawa bioaktif yang mampu menghambat pertumbuhan bakteri. Pratiwi (2014) melaporkan bahwa ekstrak batang kapuk randu mengandung beberapa senyawa bioaktif seperti alkaloid, flavonoid, tanin, saponin, hidrokuinon, triterpenoid, dan senyawa lain seperti asam borat, klorbutanol, dan benzalkonium klorida yang identik dengan senyawa pada obat tetes mata sintetik. Selain pada batang kapuk randu, pada bagian kulit batangnya juga terdapat kandungan senyawa bioaktif seperti gula pereduksi (Doughari and Ioryue, 2009), plobatanin, alkaloid, senyawa antrakuinon, saponin, glikosida (Anosike et al., 2012), tanin, fenolik, flavonoid, karbohidrat, resin, protein, minyak, steroid, dan terpenoid (Asare and Oseni, 2012), namun untuk memperoleh rendemen yang besar dalam skala laboratorium dibutuhkan jumlah batang yang banyak untuk mencukupi kebutuhan kulit batangnya.

Penggunaan pelarut berpengaruh terhadap kemampuan suatu bahan alam dalam mengisolasi senyawa bioaktif yang bersifat antibakteri. Pemilihan etanol sebagai pelarut didasarkan pada sifat selektifnya dan dapat bercampur dengan air dalam segala perbandingan. Selain bersifat ekonomis, pelarut etanol juga memiliki kemampuan dalam mengisolasi sebagian besar senyawa bioaktif. Ekstrak etanol dari bahan alam terbukti memiliki kemampuan dalam menghambat pertumbuhan bakteri. Doughari \& Ioryue (2009) melaporkan hasil penelitiannya bahwa ekstrak etanol kulit batang kapuk randu mampu menghambat beberapa jenis bakteri seperti Escherichia coli, Pseudomonas aeruginosa, Staphylococcus aureus, Shigella dysentriae, dan beberapa jenis fungi seperti Aspergillus flavus dan Candida albicans. Penelitian ini bermaksud menggunakan bagian batang kapuk randu yang akan diekstraksi dengan menggunakan pelarut etanol 30\% dan $50 \%$ untuk dibandingkan kemampuan aktivitas antibakterinya dalam menghambat pertumbuhan bakteri E. coli, $S$. aureus, dan $B$. cereus serta mengetahui senyawa bioaktif yang terkandung dalam ekstrak etanol 30\% dan 50\% batang kapuk randu dalam menghambat pertumbuhan bakteri. Penggunaan konsentrasi pelarut etanol dalam penelitian ini karena didasarkan pada efisiensi pemanfaatan pelarut dalam proses ekstraksi yang lebih mudah diperoleh dan bersifat ekonomis., selain itu pelarut tersebut juga mampu menghasilkan nilai rendemen ekstrak yang besar (Pratiwi et al., 2012) dan mampu mengisolasi senyawa bioaktif yang berpotensi sebagai antibakteri seperti senyawa golongan alkaloid dan senyawa fenolik yang lebih mudah terlarut pada pelarut yang bersifat polar (Darsana et al., 2012).

\section{METODE PENELITIAN}

Sampel berupa batang kapuk randu (C. pentandra Gaertn.) berdiameter \pm 20 cm diperoleh dari Rangkas Bitung, Kabupaten Lebak, Banten. Isolat bakteri uji diantaranya Escherichia coli ATCC 25922, Staphylococcus aureus ATCC 25923, dan Bacillus cereus. 


\section{Tahap Persiapan Sampel}

Batang kapuk randu dipotong sebelum matahari terbit, selanjutnya sebanyak $5 \mathrm{~kg}$ batang dipisahkan dengan kulitnya. Batang dipotong sampai berukuran $5 \mathrm{~cm}$, lalu dikeringkan di bawah sinar matahari. Setelah dikeringkan, batang dihaluskan dengan grinding mill sampai menjadi serbuk (simplisia) dengan ukuran 100 mesh.

\section{Proses Ekstraksi Batang Kapuk Randu}

Sebanyak $150 \mathrm{~g}$ serbuk batang dimaserasi dengan pelarut etanol $30 \%$ dan etanol 50\% hingga serbuk terendam dalam pelarut dengan perbandingan 10:1 (v/w). Setelah dilakukan perendaman selama 2 hari, dilakukan remaserasi dengan pelarut yang sama sehingga diperoleh hasil maserasi serbuk batang dengan pengulangan 2 kali (duplo). Selanjutnya hasil maserasi dilakukan pemekatan dengan menggunakan rotary evaporator pada suhu $50{ }^{\circ} \mathrm{C}$, dengan kecepatan rotary $60 \mathrm{rpm}$, selama 5 jam hingga hasil maserasi menjadi ekstrak pekat. Setelah didapatkan ekstrak pekat etanol 30\% dan etanol 50\%, kemudian ditentukan nilai rendemennya.

\section{Uji Potensi Ekstrak Etanol Batang} Kapuk Randu

Uji potensi ekstrak etanol batang kapuk randu dilakukan dengan metode difusi menggunakan kertas cakram (Tiwari et al., 2011). Kertas cakram yang mengandung tetrasiklin 100 ppm digunakan sebagai kontrol positif dan sebagai kontrol negatif digunakan kertas cakram yang mengandung DMSO. Sampel yang mempunyai potensi menghasilkan zat antibakteri ditunjukkan dengan adanya zona hambat yang terbentuk di sekitar kertas cakram untuk menentukan daya aktivitas antibakteri.

\section{Uji Aktivitas Antibakteri}

Uji aktivitas antibakteri dilakukan dengan menggunakan metode dilusi cair terhadap beberapa bakteri uji yaitu S. aureus, E. coli, dan B. cereus. Jumlah bakteri uji yang dimasukkan pada masing-masing tabung yaitu $10^{8} \mathrm{sel} / \mathrm{mL}$. Penggunaan metode dilusi cair meliputi 2 tahap pengujian yaitu penentuan Konsentrasi Hambat Minimum (KHM) dengan melihat konsentrasi terkecil dari ekstrak yang mampu menghambat pertumbuhan bakteri dan penentuan Konsentrasi Bunuh Minimum (KBM) dengan melihat konsentrasi terkecil dari ekstrak yang mampu membunuh bakteri ditandai dengan tidak adanya pertumbuhan bakteri pada cawan. Konsentrasi ekstrak etanol batang kapuk randu (C. pentandra Gaertn.) yang digunakan yaitu $10 \mathrm{mg} / \mathrm{mL}, 8$ $\mathrm{mg} / \mathrm{mL}, 6 \mathrm{mg} / \mathrm{mL}, 4 \mathrm{mg} / \mathrm{mL}$, dan 2 $\mathrm{mg} / \mathrm{mL}$ setara dengan $10.000 \mathrm{ppm}$, 8.000 ppm, 6.000 ppm, 4.000 ppm, dan $2.000 \mathrm{ppm}$. Sebagai kontrol positif digunakan tetrasiklin 100 ppm dan kontrol negatif yaitu menggunakan dimetilsulfoksida (DMSO).

\section{Penentuan KHM dan KBM}

Perlakuan pada masing-masing tabung uji dengan berbagai varian konsentrasi ekstrak diinkubasi pada suhu $37^{\circ} \mathrm{C}$ selama $18-24$ jam. Setelah diinkubasi selanjutnya dilakukan penentuan nilai Konsentrasi Hambat Minimum (KHM) dengan menumbuhkan suspensi pada tabung uji dengan varian konsentrasi pada medium MHA. Kemudian diinkubasi pada suhu $37{ }^{\circ} \mathrm{C}$ selama $18-24$ 
jam. Setelah diinkubasi dilakukan perhitungan jumlah koloni sesuai dengan peraturan Standard Plate Count (SPC) dan perhitungan persentase penghambatan bakteri. Konsentrasi terendah yang mampu menghambat pertumbuhan bakteri sebanyak $90 \%$ dari inokulum awal selama inkubasi 18-24 jam merupakan nilai KHM ekstrak. Konsentrasi Bunuh Minimum (KBM) ditentukan pada konsentrasi ekstrak terkecil yang tidak terdapat pertumbuhan koloni bakteri.

\section{Uji Fitokimia Senyawa Bioaktif}

Uji fitokimia senyawa bioaktif dilakukan terhadap senyawa Alkaloid, Tanin, Asam Borat, dan Benzalkonium Klorida.

\section{Analisis Data}

Penentuan nilai Konsentrasi Hambat Minimum (KHM) ekstrak etanol batang kapuk randu dilakukan dengan menentukan nilai persentase penghambatan terhadap bakteri $E$. coli, S. aureus, dan B. cereus. Data yang diperoleh dari penentuan nilai KHM dan KBM serta pengujian fitokimia dianalisis secara deskriptif.

\section{HASIL DAN PEMBAHASAN}

\section{Ekstraksi Batang Kapuk Randu}

Proses ekstraksi batang kapuk randu dilakukan dengan menggunakan metode maserasi dengan pelarut etanol. Maserasi merupakan cara penyarian sederhana yang dilakukan dengan merendam serbuk simplisia tanaman pada suatu wadah tertutup dalam jangka waktu tertentu (Tiwari et al., 2011). Proses maserasi dilakukan dengan perendaman menggunakan pelarut etanol selama 2 hari yang bertujuan untuk mengendapkan senyawasenyawa yang tidak diinginkan yang ikut terisolasi dalam pelarut etanol. Setelah itu dilakukan remaserasi sebanyak 2 kali dengan tujuan agar senyawa yang terisolasi dalam pelarut etanol lebih banyak.

Penggunaan metode ekstraksi dengan maserasi dalam penelitian memiliki keuntungan antara lain tidak melakukan proses pemanasan sehingga senyawa-senyawa yang bersifat labil tidak mudah rusak maupun menghilang oleh adanya perlakuan pemanasan, selain itu metode ekstraksi lebih mudah dalam pengerjaannya dan menggunakan peralatan yang sederhana (Wardhani dan Sulistyani, 2012).

Tabel 1. Karakteristik ekstrak etanol batang kapuk randu dengan maserasi

\begin{tabular}{|l|c|c|}
\hline \multirow{2}{*}{$\begin{array}{c}\text { Karakteristik } \\
\text { Ekstrak }\end{array}$} & \multicolumn{2}{|c|}{ Hasil } \\
\cline { 2 - 3 } & Etanol 30\% & Etanol 50\% \\
\hline Warna Ekstrak & Coklat & Coklat \\
\hline Berat Ekstrak & 6,68 gram & 10,79 gram \\
\hline Rendemen & $4,45 \%$ & $7,19 \%$ \\
\hline $\begin{array}{l}\text { Senyawa Bio- } \\
\text { aktif }\end{array}$ & $\begin{array}{c}\text { Saponin, Fla- } \\
\text { vonoid, dan } \\
\text { Tanin }\end{array}$ & $\begin{array}{c}\text { Saponin, Fla- } \\
\text { vonoid, dan } \\
\text { Tanin }\end{array}$ \\
\hline
\end{tabular}

Berdasarkan perbandingan nilai rendemen yang dihasilkan dari ekstrak etanol 30\% dan 50\% batang kapuk randu, ekstrak etanol 50\% memiliki nilai rendemen ekstrak lebih tinggi dibandingkan pada ekstrak etanol 30\% dengan selisih 2,74\%. Hal ini disebabkan ekstrak etanol 50\% merupakan pelarut yang memiliki tingkat kepolaran yang sama dengan senyawa penyusun pada serbuk batang kapuk randu.

Berdasarkan penelitian mengenai optimalisasi ekstraksi komponen senyawa bioaktif pada daun tabat barito (Ficus deltoidea) menerangkan bahwa kelarutan suatu senyawa bioaktif dalam pelarut terutama 
dipengaruhi oleh persamaan kepolaran antara pelarut dan senyawa bioaktif yang terkandung pada bahan. Senyawa bioaktif hanya akan larut pada pelarut yang relatif sama kepolarannya. Semakin dekat tingkat kepolaran pelarut dengan tingkat kepolaran senyawa penyusun bahan maka semakin tinggi nilai rendemen yang dihasilkan. Setiap pelarut memiliki kemampuan yang berbeda dalam mengisolasi senyawa bioaktif dan tingginya nilai rendemen tidak selalu berbanding lurus dengan aktivitas antibakterinya (Pratiwi et al., 2012).

\section{Potensi Ekstrak Etanol Batang Kapuk Randu sebagai Antibakteri}

Penggunaan pelarut etanol dalam proses ekstraksi dari beberapa ekstrak tanaman terbukti memiliki aktivitas antibakteri terhadap bakteri dan fungi. Ekstrak etanol mampu menghambat pertumbuhan beberapa bakteri seperti ekstraketanol dari daun mayana (Coleus atropurpureus L. Benth) terbukti memiliki aktivitas sebagai antibakteri terhadap S. aureus dan E. coli serta ekstrak etanol daun beluntas (Pluchea indica L.) juga memiliki aktivitas antibakteri terhadap bakteri S. aureus (Manu, 2013). Penentuan potensi ekstrak etanol batang kapuk randu sebagai antibakteri dilakukan dengan menggunakan metode difusi cakram Kirby-Bauer. Konsentrasi ekstrak etanol batang kapuk randu yang digunakan ialah sebesar $10 \mathrm{mg} /$ mL. Dasar pemilihan konsentrasi ekstrak etanol batang kapuk randu $10 \mathrm{mg} / \mathrm{mL}$ yaitu untuk mengetahui kemampuannya dalam menghambat pertumbuhan bakteri E. coli, S. aureus, dan B. cereus.

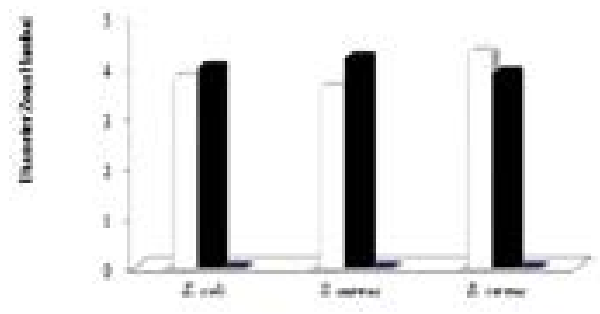

Gambar 1. Diameter zona hambat pertumbuhan bakteri pada ekstrak etanol batang kapuk randu $30 \%(\square)$ dan $50 \%(\square)$.

Gambar 1 menunjukkan bahwa aktivitas ekstrak etanol $30 \%$ batang kapuk randu konsentrasi $10 \mathrm{mg} /$ $\mathrm{mL}$ lebih peka dalam menghambat pertumbuhan bakteri Gram positif $B$. cereus bila dibandingkan dengan bakteri Gram positif $S$. aureus dan Gram negatif E. coli. Aktivitas ekstrak etanol $50 \%$ batang kapuk randu konsentrasi $10 \mathrm{mg} / \mathrm{mL}$ juga lebih peka dalam menghambat pertumbuhan bakteri Gram positif $S$. aureus bila dibandingkan dengan bakteri Gram positif B. cereus dan Gram negatif E. coli. Perbedaan penghambatan bakteri uji oleh ekstrak etanol 30\% dan $50 \%$ batang kapuk randu dalam menghambat pertumbuhan bakteri uji disebabkan adanya perbedaan struktur dinding sel kedua jenis bakteri Gram tersebut. Dinding sel merupakan bagian terpenting dari sel bakteri karena berperan melindungi kerusakan sel dari lingkungan bertekanan osmotik rendah dan menyediakan komponen struktural yang kaku dan kuat sehingga dapat memberi bentuk sel (Dianita et al., 2013).

Bakteri Gram positif memiliki struktur dinding sel dengan lebih banyak peptidoglikan, sedikit lipid dan dinding sel mengandung polisakarida (asam teikoat). Asam teikoat berfungsi sebagai transport 
ion positif untuk keluar atau masuknya ion. Sifat larut air inilah yang menunjukkan bahwa dinding sel bakteri Gram positif bersifat lebih polar. Senyawa bioaktif seperti flavonoid, saponin, dan tanin dalam batang kapuk randu merupakan bagian yang bersifat polar sehingga lebih mudah menembus lapisan peptidoglikan yang bersifat polar daripada lapisan lipid yang nonpolar. Hal ini menyebabkan aktivitas penghambatan pada bakteri Gram positif lebih besar daripada bakteri Gram negatif. Bakteri Gram negatif lebih banyak mengandung lipid, sedikit peptidoglikan, membran luar berupa bilayer (berfungsi sebagai pertahanan selektif senyawasenyawa yang keluar atau masuk sel dan menyebabkan efek toksik). Membran luar terdiri dari fosfolipid (lapisan dalam), dan lipopolisakarida (lapisan luar) tersusun atas lipid A, yang bersifat nonpolar. Hal ini juga menyebabkan senyawa antibakteri pada batang kapuk randu lebih sulit untuk masuk ke dalam sel sehingga aktivitas antibakterinya lebih lemah dibandingkan pada bakteri Gram positif. Pada penelitian terlihat bahwa penghambatan terhadap Bacillus cereus dan Staphylococcus aureus oleh ekstrak batang kapuk randu lebih besar dibandingkan Escherichia coli.

Diameter zona hambat yang dibentuk olehkontrol positif antibiotik tetrasiklin lebih besar pada bakteri Gram positif $S$. aureus dan bakteri Gram negatif E. coli sebesar $15 \mathrm{~mm}$ dibandingkan bakteri Gram positif B. cereus sebesar $12 \mathrm{~mm}$. Antibiotik tetrasiklin dipilih sebagai kontrol positif karena tetrasiklin merupakan salah satu antibiotik yang sudah lama digunakan untuk pengobatan penyakit infeksi pada manusia dan hewan. Antibiotik tersebut ditemukan sekitar 50 tahun yang lalu. Mekanisme aksi dari antibiotik tetrasiklin ialah menghambat sintesis protein bakteri dengan cara mencegah asosiasi aminoacyl-tRNA dengan ribosom bakteri. Tetrasiklin memiliki aktivitas antibakteri broad spectrum terhadap bakteri Gram positif dan Gram negatif (Chopra and Roberts, 2001). Hasil pengukuran diameter zona hambat kontrol positif terhadap ketiga bakteri uji menunjukkan bahwa tetrasiklin memiliki efek antibakteri yang lebar (spektrum luas) karena memiliki kisaran inang baik terhadap bakteri Gram positif maupun bakteri Gram negatif. Tetrasiklin dengan konsentrasi 100 ppm sebagai kontrol positif dikategorikan kuat dalam penghambatannya terhadap bakteri E. coli, S. aureus, dan B. cereus.

Batang kapuk randu dengan ekstrak pelarut etanol 30\% dan 50\% memiliki daya hambat yang berbeda terhadap bakteri Gram positif, namun tidak lebih kuat kekuatan daya antibakterinya jika dibandingkan dengan tetrasiklin sebagai kontrol positif. Penggunaan konsentrasi pelarut yang berbeda diduga mempengaruhi kekuatan daya hambat ekstrak batang kapuk randu terhadap bakteri uji.

Diameter zona hambat yang dihasilkan ekstrak etanol 30\% dan $50 \%$ batang kapuk randu bila dibandingkan dengan kontrol positif antibiotik tetrasiklin menunjukkan hasil yang tidak sebanding. Hal ini disebabkan oleh perbedaan kandungan senyawa, dimana pada antibiotik tetrasiklin sudah melalui proses purifikasi sehingga senyawanya lebih bersifat murni jika dibandingkan ekstrak etanol batang kapuk randu yang masih crude extract. 
Belum murninya ekstrak etanol batang kapuk randu yang digunakan diduga membuat penghambatan terhadap bakteri belum terlalu maksimal. Selain itu konsentrasi ekstrak etanol batang kapuk randu yang digunakan hanya sebesar $10 \mathrm{mg} / \mathrm{mL}$ atau setara dengan 1\% (1000 ppm).

\section{Konsentrasi Hambat Minimum (KHM)}

Nilai KHM ekstrak etanol 30\% batang kapuk randu terhadap bakteri E. coli adalah pada konsentrasi 8 $\mathrm{mg} / \mathrm{mL}$ yang menunjukkan bahwa pada konsentrasi tersebut mampu menghambat pertumbuhan bakteri sebesar $92,55 \%$.

Nilai KHM ekstrak etanol 30\% batang kapuk randu terhadap bakteri S. aureus adalah pada konsentrasi 6 $\mathrm{mg} / \mathrm{mL}$, dimana pada konsentrasi tersebut mampu menghambat pertumbuhan bakteri sebesar $90,35 \%$. Nilai KHM ekstrak etanol 30\% batang kapuk randu terhadap bakteri $B$. cereus adalah pada konsentrasi 6 $\mathrm{mg} / \mathrm{mL}$ yang menunjukkan bahwa pada konsentrasi tersebut mampu menghambat pertumbuhan bakteri sebesar $90,59 \%$. Nilai persentase penghambatan bakteri S. aureus dan B. cereus lebih besar atau konsentrasi ekstrak lebih kecil dibandingkan dengan bakteri E. coli. Hal ini menunjukkan bahwa bakteri $S$. aureus dan B. cereus lebih sensitif dibandingkan dengan bakteri $E$. coli terhadap ekstrak etanol $30 \%$ batang kapuk randu. Aktivitas antibakteri suatu ekstrak tergantung pada konsentrasi ekstrak yang diberikan.

Nilai KHM ekstrak etanol 50\% batang kapuk randu terhadap bakteri E. coli adalah pada konsentrasi $8 \mathrm{mg} /$
$\mathrm{mL}$, hal ini menunjukkan bahwa pada konsentrasi tersebut mampu menghambat pertumbuhan bakteri sebesar 91,02\%. Nilai KHM ekstrak etanol $50 \%$ batang kapuk randu terhadap bakteri $S$. aureus adalah pada konsentrasi $10 \mathrm{mg} / \mathrm{mL}$, dimana pada konsentrasi tersebut mampu menghambat pertumbuhan bakteri sebesar 98,36\%. Nilai KHM ekstrak etanol $50 \%$ batang kapuk randu terhadap bakteri $B$. cereus adalah pada konsentrasi $8 \mathrm{mg} / \mathrm{mL}$ yang menunjukkanbahwa padakonsentrasi tersebut mampu menghambat pertumbuhan bakteri sebesar $90,88 \%$. Nilai persentase penghambatan bakteri E. coli dan B. cereus lebih besar atau konsentrasi ekstrak lebih kecil dibandingkan dengan bakteri $S$. aureus. Hal ini menunjukkan bahwa bakteri E. coli dan B. cereus lebih sensitif dibandingkan dengan bakteri S. aureus terhadap ekstrak etanol $50 \%$ batang kapuk randu.

Ada beberapa kriteria sifat daya antibakteri berdasarkan nilai $\mathrm{KHM}$ yaitu, nilai KHMkurang dari $16 \mu \mathrm{g} / \mathrm{mL}$ dikategorikan bersifat sensitif, nilai KHM 16-128 $\mu \mathrm{g} / \mathrm{mL}$ dikategorikan bersifat moderat atau intermediet, dan nilai KHM lebih dari $128 \mu \mathrm{g} / \mathrm{mL}$ dikategorikan bersifat resisten (Tiwari et al., 2011). Berdasarkan kriteria tersebut, ekstrak etanol 30\% batang kapuk randu dikategorikan bersifat resisten terhadap E. coli sebesar $8 \mathrm{mg} /$ $\mathrm{mL}(8.000 \mu \mathrm{g} / \mathrm{mL})$, terhadap S. aureus dan B. cereus sebesar $6 \mathrm{mg} / \mathrm{mL}(6.000$ $\mu \mathrm{g} / \mathrm{mL}$ ). Ekstrak etanol $50 \%$ batang kapuk randu juga dikategorikan bersifat resisten terhadap E. coli dan B. cereus sebesar $8 \mathrm{mg} / \mathrm{ml}(8.000 \mu \mathrm{g} /$ $\mathrm{mL}$ ) dan terhadap $S$. aureus sebesar 10 $\mathrm{mg} / \mathrm{mL}(10.000 \mu \mathrm{g} / \mathrm{mL})$. 


\section{Konsentrasi Bunuh Minimum (KBM)}

Ekstrak etanol $30 \%$ memiliki aktivitas antibakteri terhadap bakteri S. aureus dengan KBM yaitu $10 \mathrm{mg} / \mathrm{mL}$, sedangkan pada $E$. coli dan B. cereus sampai pada konsentrasi ekstrak $10 \mathrm{mg} / \mathrm{mL}$ tidak dapat membunuh atau tidak menunjukkan adanya aktivitas antibakteri. Ekstrak etanol $50 \%$ memiliki aktivitas antibakteri terhadap bakteri $B$. cereus dengan KBM yaitu $10 \mathrm{mg} / \mathrm{mL}$, sedangkan pada E. coli dan S. aureus sampai pada konsentrasi $10 \mathrm{mg} / \mathrm{mL}$ tidak dapat membunuh atau tidak menunjukkan adanya aktivitas antibakteri. Hal ini disebabkan pada ekstrak etanol 50\% diduga memiliki senyawa bioaktif yang serupa dengan ekstrak etanol $30 \%$, sehingga pada konsentrasi $100 \%$ $\mathrm{b} / \mathrm{v}$ ekstrak etanol 50\% memiliki kemampuan yang sama dalam menghambat pertumbuhan bakteri uji dalam hal ini bakteri B. cereus yang termasuk ke dalam bakteri Gram positif.

Kemampuan ekstrak etanol $30 \%$ dan 50\% dalam menghambat pertumbuhan bakteri uji diduga disebabkan oleh adanya perbedaan komposisi penyusun tubuh bakteri uji yaitu struktur dinding sel antara bakteri $S$. aureus dan $B$. cereus yang termasuk bakteri Gram positif dengan bakteri $E$. coli yang termasuk bakteri Gram negatif. Dinding sel merupakan bagian yang terpenting dari sel bakteri karena berfungsi melindungi kerusakan sel dari lingkungan bertekanan osmotik rendah dan menyediakan komponen struktural yang kaku dan kuat sehingga dapat memberi bentuk sel (Sari et al., 2010).

Dinding sel bakteri Gram positif memiliki struktur dinding sel lebih sederhana dibandingkan struktur dinding sel pada bakteri Gram negatif yang lebih kompleks. Kompleksitas dinding sel bakteri tersebut kemungkinan dapat menghambat obat atau ekstrak antibakteri yang diujikan (Sari et al., 2010). Bakteri Gram positif memiliki kandungan lipid dinding sel yang rendah sedangkan bakteri Gram negatif memiliki kandungan lipid yang tinggi yaitu $11-12 \%$. Kandungan lipid yang rendah pada bakteri Gram positif memudahkan senyawa bioaktif yang terkandung pada ekstrak etanol 30\% masuk ke dalam dinding sel bakteri Gram positif yang strukturnya lebih sederhana dibandingkan dengan bakteri Gram negatif.

Berdasarkan kemampuan ekstrak etanol batang kapuk randu dalam menghambat pertumbuhan bakteri, ekstrak etanol batang kapuk randu tergolong ke dalam kelompok zat antibakteri yang bersifat bakteriostatik dan bakterisida. Kemampuan zat antibakteri dikatakan bersifat bakteriostatik apabila mampu menghambat populasi bakteri tetapi tidak mematikan bakterinya, sedangkan zat antibakteri yang bersifat bakterisida apabila mampu membunuh populasi bakteri. Beberapa zat antibakteri ada yang bersifat bakteriostatik namun dapat berubah menjadi bakterisida jika digunakan dalam dosis tinggi (Manu, 2013).

Ekstrak etanol $30 \%$ pada konsentrasi $4 \mathrm{mg} / \mathrm{mL}$ sampai $10 \mathrm{mg} /$ $\mathrm{mL}$ bersifat bakteriostatik terhadap S. aureus, E. coli, dan B. cereus, kecuali pada konsentrasi $10 \mathrm{mg} /$ $\mathrm{mL}$ dari ekstrak etanol 30\% yang bersifat bakterisida terhadap bakteri S. aureus. Ekstrak etanol 50\% juga menunjukkan hasil serupa yaitu pada konsentrasi $6 \mathrm{mg} / \mathrm{mL}$ sampai $10 \mathrm{mg} /$ 
$\mathrm{mL}$ bersifat bakteriostatik terhadap S. aureus, E. coli, dan B. cereus, kecuali pada konsentrasi $10 \mathrm{mg} / \mathrm{mL}$ dari ekstrak etanol $50 \%$ yang bersifat bakterisida terhadap bakteri B. cereus. Berdasarkan hasil, ekstrak etanol $30 \%$ dan $50 \%$ batang kapuk randu dapat dikategorikan ke dalam zat antibakteri yang memiliki spektrum sempit, karena hanya mampu membunuh bakteri Gram positif saja, namun perlu dilakukan penelitian lebih lanjut dari ekstrak etanol $30 \%$ dan $50 \%$ batang kapuk randu terhadap bakteri Gram negatif selain E. coli.

\section{Uji Fitokimia Ekstrak Etanol Batang Kapuk Randu}

Kemampuan ekstrak etanol batang kapuk randu erat kaitannya dengan peranan senyawa bioaktif dalam menghambat pertumbuhan bakteri. Berdasarkan hasil uji fitokimia pada ekstrak etanol 30\% dan 50\% (Tabel 1), diketahui bahwa senyawa ekstrak etanol $30 \%$ dan $50 \%$ mengandung senyawa bioaktif yaitu saponin, flavonoid, dan tanin. Saponin memiliki peranan penting dalam menghambat pertumbuhan bakteri, karena saponin bekerja dengan mengganggu stabilitas membran sel bakteri sehingga menyebabkan sel bakteri lisis dan menyebabkan keluarnya berbagai komponen penting dari dalam sel bakteri seperti protein, asam nukleat, dan nukleotida (Rosyidah et al., 2010). Saponin akan mengubah tegangan permukaan dan mengikat lipid pada sel bakteri yang menyebabkan lipid terekskresi dari dinding sel sehingga permeabilitas membran bakteri terganggu (Wardhani dan Sulistyani, 2012). Tidak ada perbedaan antara senyawa bioaktif yang terkandung pada ekstrak etanol $30 \%$ dan $50 \%$ batang kapuk randu. Hal ini diduga disebabkan oleh kedua ekstrak etanol tersebut memiliki kemampuan yang sama dalam melarutkan senyawa yang bersifat polar dan perbedaan konsentrasi pelarut ekstrak etanol tidak mempengaruhi kandungan senyawa bioaktif (Wardhani dan Sulistyani, 2012).

\section{SIMPULAN, SARAN, DAN REKOMENDASI}

Simpulan yang dapat diambil dari hasil penelitian ini antara lain ekstrak etanol batang kapuk randu memiliki aktivitas antibakteri terhadap E. coli, S. aureus, dan B. cereus dengan diameter zona hambat tertinggi pada konsentrasi $10 \mathrm{mg} / \mathrm{mL}$ ekstrak etanol $30 \%$ dan $50 \%$ secara berurutan. Ekstrak etanol $30 \%$ dan $50 \%$ batang kapuk randu dikategorikan ke dalam zat antibakteri yang memiliki spektrum sempit walaupun memiliki kandungan senyawa bioaktif saponin, flavonoid, dan tanin.

Ekstrak yang diperoleh seharusnya lebih banyak lagi agar penelitian selanjutnya bisa dilakukan purifikasi dan ditentukan strukturnya, lalu diujikan pada bakteri uji patogen lainnya.

\section{UCAPAN TERIMA KASIH}

Terima kasih kepada LPPM UNINDRA dan Direktorat Jenderal Pendidikan Tinggi Kementerian Pendidikan dan Kebudayaan atas Dana Riset Hibah Bersaing DIKTI tahun 2013 dengan nomor kontrak: 015/K3.KM/2013, tanggal 13 Mei 2013 atas nama RHP.

\section{DAFTAR PUSTAKA}

Anosike,C.A.,Ogili,O.B.,Nwankwo,O.N., and Eze, E.A. 2012. Phytochemical Screening and Antimicrobial Activity of The Petroleum Ether, Methanol and Ethanol Extracts of Ceiba pentandra stem bark. Journal of Medicinal Plants Research 6(46): 5743-5747. 
Asare, P., and Oseni, L.A. 2012. Comparative Evaluation of Ceiba pentandra Ethanolic Leaf Extract, Stem Bark Extract and The Combination Thereof for In Vitro Bacterial Growth Inhibition. Journal of Natural Sciences Research 2(5): 44-49.

Chopra, I., and Roberts, M. 2001. Tetracycline Antibiotics: Mode of Action, Applications, Molecular Biology, and Epidemiology of Bacterial Resistance. Microbiology and Molecular Biology Reviews 65(2): 232260.

Darsana, I.G.O. 2012. Besung INK, Mahatmi H. Potensi Daun Binahong (Anredera cordifolia (Tenore) Steenis) dalam Menghambat Pertumbuhan Bakteri Escherichia coli secara In Vitro. Indonesia Medicus Veterinus 1(3): 337351.

Dianita, Y., Nur, S., dan Hayu, L. 2013. Uji aktivitas antibakteri infusa daun sirsak (Annona muricata L.) secara in vitro terhadap Staphylococcus aureus ATCC 25923 dan Escherichia coli ATCC 35218 serta profil kromatografi lapis tipisnya. Fakultas Kesehatan Masyarakat, Universitas Akhmad Dahlan.

Doughari, J.H., and Ioryue, A.S. 2009. Antimicrobial Activity of Stem Bark Extracts of Ceiba pentandra. Pharmacology online 1: 1333-1340.

Manu, R.R.S. 2013. Aktivitas Antibakteri Ekstrak Etanol Daun Beluntas (Pluchea indica L.) Terhadap Staphylococcus aureus, Bacillus subtilis dan Pseudomonas aeroginosa. Jurnal Ilmiah Mahasiswa Universitas Surabaya 2(1): 1-10.
Pratiwi, R.H., Purwakusumah, E.D., dan Emilda. 2012. Potensi air dan batang Ceiba pentandra Gaertn. sebagai antibakteri penyebab penyakit konjungtivitis. Prosiding Simposium Nasional Kimia Bahan Alam XX. Banten 9-10 Oktober, 2012. Pp. 246-262.

Pratiwi, R.H. 2014. Potensi kapuk randu (Ceiba pentandra Gaertn.) dalam penyediaan obat herbal. Widya Kesehat an dan Lingkungan 1(1): 53-60.

Rosyidah, K., Nurmuhaimina, S.A., Komari, N., dan Astuti, M.D. 2010. Aktivitas Antibakteri Fraksi Saponin dari Kulit Batang Tumbuhan Kasturi (Mangifera casturi). Bioscientiae 7(2): 25-31.

Sari, Y.D., Djannah, S.N., dan Nurani, L.H. 2010. Uji Aktivitas Antibakteri Infusa Daun Sirsak (Annona muricata L.) secara In Vitro terhadap Staphylococcus aureus ATCC 25923 dan Escherichia coli ATCC 35218 serta Profil Kromatografi Lapis Tipisnya. KESMAS 4(3): 144-239.

Tiwari, P., Kumar, B., Kaur, M., Kaur, G., and Kaur, H. 2011. Phytochemical Screening and Extraction: A Review. International Pharmaceutica Sciencia 1(1): 1-9.

Wardhani, L.K., dan Sulistyani, N. 2012. Uji Aktivitas Antibakteri Ekstrak Etil Asetat Daun Binahong (Anredera scandens (L.) Moq.) Terhadap Shigella flexneri Beserta Profil Kromatografi Lapis Tipis. Jurnal Ilmiah Kefarmasian 2(1): 1-16. 